\title{
Moğolların Meyyâfârikîn Kuşatması
}

\author{
Mert Demir* - Mustafa Şahin**
}

(ORCID: 0000-0472-3993-4584-0000-0002-4897-4053)

Makale Gönderim Tarihi

31.08.2020
Makale Kabul Tarihi

29.03.2021

\section{Atıf Bilgisi/Reference Information}

Chicago: Demir, M. - Şahin, M., "Moğolların Meyyâfârikîn Kuşatması", Vakanüvis-Uluslararası Tarih Araştırmaları Dergisi, 6/1 (2021): 381-406.

APA: Demir, M. - Şahin, M. (2021). Moğolların Meyyâfârikîn Kuşatması. Vakanüvis-Uluslararası Tarih Araştırmaları Dergisi, 6 (1) , 381-406.

\section{Özet}

Cengiz Han'ın ölümünden kısa bir süre sonra Moğol İmparatorluğu'nun toprakları üzerinde dört büyük devlet açığa çıktı. Bu devletlerden biri de merkezi Tebriz olmak üzere Hülagü Han'ın kurduğu ilhanlılardır.

Hülagü, Mengü Han tarafından imparatorluğun batı kısmına görevlendirildi. $\mathrm{O}$ da kendisine verilen görevi yerine getirmek için yola çıktı. 1256 yılında İsmâilîlere, 1258 yılında Abbâsî Halîfeliği'ne son verdi. Daha sonra üçüncü görevi olan Suriye ve Mısır'ı almak için Azerbaycan'dan harekete geçti. Bağdad kuşatması sırasında Abbâsî Halîfeliği'ne destek olmak amacıyla asker gönderen ve Moğollara tâbi olmayı reddeden Eyyûbîlerin Meyyâfârîkîn hâkimi el-Kâmil'in itaat altına alınması için oğlu Yaşmut'u görevlendirdi. Moğol ordusunda Bedreddîn Lü’lü gibi Müslüman müttefiklerin yanı sıra Ermeni ve Gürcü birlikler de bulunuyordu. Yaşmut, teslim olması için el-Kâmil'e elçi gönderdi. Teklifi reddeden el-Kâmil, sağlam surlara sahip Meyyâfârikîn şehrini, halkıyla yekvücut olup savunmaya başladı. Yaklaşık iki yıl boyunca kuşatma altına alınan Meyyâfârikîn açlık ve susuzluğa mahkûm edildikten sonra teslim olmak zorunda

\footnotetext{
* Yüksek Lisans Öğrencisi, Amasya Üniversitesi Sosyal Bilimler Enstitüsü, barışdemir@hotmail.com.

** Doç. Dr. Amasya Üniversitesi Fen Edebiyat Fakültesi Tarih Bölümü, mustafa.sahin@amasya.edu.tr.
}

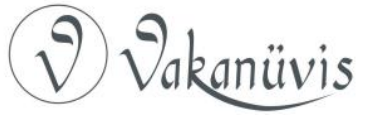


kaldı. Şehir teslim alındıktan sonra burada kalan insanlar Moğollar tarafından katledildi. Hülagü'nün emriyle, el-Kâmil'in vücudundan koparılan et parçaları ağzına verilerek yapılan işkence ile öldürüldü. El-Kâmil'in kesilen başı Suriye'nin büyük şehirlerinde Moğollar ve onların destekçileri tarafından zafer nişânesi olarak dolaştırıldıktan sonra bir mızrağın ucuna takılarak uzun bir müddet teşhir edildi. Ayn-ı Calut Savaşı'nı kazanan Memlûkler onun kesik başını Şam'da defnettiler. Kuşatma ile harap olan Meyyâfârikîn ise uzun bir müddet kendini toparlayamayarak küçük bir şehir halinde kaldı.

Bu çalışmanın amacı; Meyyâfârikîn halkının Moğollara karşı direnişin sembolü haline gelmelerini ilim âlemine ayrıntılı şekilde tanıtmaktır.

Anahtar Kelimeler: Moğollar, Eyyûbîler, Meyyâfârikîn, el-Kâmil, Yaşmut.

\section{Mongol Siege of Mayyafariqin}

\section{Abstract}

Shortly after Genghis Khan's death, four big states were founded on the lands Mongolian Empire's. One of them was the Ilkhanid State founded by Hülagü, with Tabriz its capital.

Hülagü was assigned to the western part of the Empire by Mangu Han. He set out in 1253 to fulfill his mission. Putting an end to the rule of the Ismailis in 1256 and the Abbasid Caliphate in 1258, He later moved from Azerbaijan to conquer Syria and Egypt as his third mission. He commissioned his son Yaşmut to subjugate Ayyubid Ruler of Mayyafariqin, al-Kamil, who had sent troops to support the Abbasid Caliphate during the siege of Baghdad and refused to obey the Mongols. The Mongol army incluced Armenian and Georgian troops as well as Muslim allies like Bedreddîn Lulu. Yaşmut sent ambassador to al-Kamil to demand his surrender. Al-Kamil, who rejected the offer, started to defend the city of Mayyafariqin which had strong walls with his people. The city had to surrender due to hunger and thirst upon a siege that lasted about two years. After the city was takenover, itsdwellers wereslaughtered by the Mongols. With Hülagü's order, al-Kamil was killed by torture, in which pieces of flesh torn from his body was forced into his mouth. After the severed head of al-Kamil was passed arround in big cities of Syria by the Mongols and their supporters as asign of victory, it was attached to the end of spear and displayed for a long time. Winning the Battle of Ain Jalut, the Mamluks buried his severed head in Damascus. Mayyafariqin, destroyed with the siege, could not pull itself together for a long time and remaining as a small city.

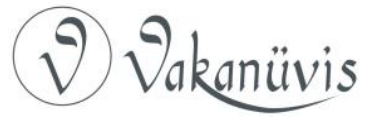


The article aims to introduce how for the world of science Mayyafaqirin became the symbol of resistance against the Mongols.

Keywords: Mongols, Ayyubids, Mayyafariqin, al-Kamil, Yaşmut.

\section{Giriş}

Meyyâfârikîn, Orta Çağ'ın önemli yerleşim merkezlerinden birisidir. Güneydoğu Toros Dağları'nın eteklerinde ve Dicle Nehri'nin sol tarafında uzanan ve yaklaşık 5-6 bin hektarlık alanı kaplayan Silvan Ovası'nda yer alır. Bugün Silvan adıyla bilinen şehir, el-Cezîre bölgesinin ${ }^{1}$ önemli bir kısmını oluşturmaktadır. ${ }^{2}$ Çok elverişli bir iklime sahip olduğu için eskiden beri burada çeşitli meyveler ve sebzeler bolca yetişmektedir. ${ }^{3}$

Şehrin ismi Ermenice'de "Nouphargerd", Süryanice'de "Maipherkat" olarak geçmektedir. ${ }^{4}$ Vardan, Aknerli Grigor ve Genceli Kiragos'un

\footnotetext{
${ }^{1}$ El-Cezîre; Dicle ve Fırat nehirleri arasında bulunan alandır. Batı sınırı Fırat Nehri'ne paralel olup bu sınır güneybatıya doğru Malatya, Samsat, Rumkale, Birecik, Menbiç'in karşısına Rakka ve Karkısiye, boyunca uzanır. Bol akarsuyu ve ılıman iklimi nedeniyle geçmişte mâmûr bir bölge olmuştur. Bkz. Hudûdü'l-Âlem Mine'l-Meşrik Ile'l-Magrib, Çev. Abdullah Duman-Murat Ağarı, Kitabevi Yay., İstanbul 2008, s. 99; Ebü'l-Fidâ, Ebü'lFidâ Coğrafyası, Çev. Ramazan Şeşen, İstanbul 2017, s. 231.

2 Sa'd b. Muhammed Huzeyfe el-Ğamdi, "Meyyafarikin'de Kahramanlık ve Fedakârlık", Çev. Mehdi ilhan, AÜDTCF Tarih Araştırmaları Dergisi, C. 29, S. 47, (Ankara 1986), s. 230. 3 Hamdullah Müstevfî-yi Kazvînî (Hamd-Allah Mustawfi of Qazwîn), The Geographical Part of the Nuzhat al-Qulub, Trans. G. Le Strange, Leyden/London 1919, s. 105.

${ }^{4}$ El-Ğamdi, a.g.m., s. 231; Mustafa Alican, Bir Orta Çağ Şehri Olarak Meyyâfârikîn (Silvan), Ege Üniversitesi Sosyal Bilimler Enstitüsü Tarih Anabilim Dalı Yayınlanmamış Doktora Tezi, İzmir 2012, s. 35.
}

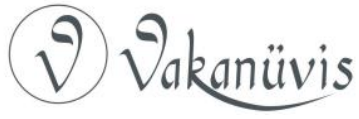


eserlerinde "Martyrpolis" (Şehitler Şehri) olarak kaydedilmiştir. ${ }^{5}$ Bu isimlere ilaveten geçmişte şehre Cefakeşler Şehri de denilmiştir. ${ }^{6}$

Meyyâfârikîn'in etrafı taşlardan inşâ edilmiş yüksek bir sur ile çevriliydi. Şehirdeki Bizans İmparatorluğu'ndan kalma kale ve bu kalenin etrafındaki surlar Moğolların şehri kuşatmak için geldikleri sırada hâlâ sağlamdı. Bu surlar şehrin alınmasını güçleştiriyordu. ${ }^{7}$ Şehrin üç kulesi ve sekiz kapısı vardı. Bu kapılar İmparator Theodosius zamanından kalmıştı. ${ }^{8}$

Büyük ölçüde dönemin kaynakları kullanılan, bunun yanında günümüz araştırmacılarının eserlerinden de çokça istifade edilen bu çalışmanın amacı; el-Kâmil'in şahsında Meyyâfârikîn şehrinin Moğollara karşı direnişin sembolü haline geldiğini ayrıntılı bir şekilde anlatmaktır.

\section{Moğol Kuşatmasına Kadar Meyyâfârikîn Şehri}

Meyyâfârikîn'e ilk yerleşimin tarihi $\mathrm{Hz}$. İsâ'dan önceki dönemlere kadar gitmektedir. ${ }^{9}$ M.Ö. 600 yılından kalma tarihi eserler şehrin çok eski bir yerleşim yeri olduğunu göstermektedir. ${ }^{10}$

Meyyâfârikîn Moğol istilasına kadar birçok devletin hâkimiyetinde kalmıştır. Şehir, IV. yüzyılın ikinci yarısında Roma İmparatorluğu'nun, V. yüzyılın sonlarında Bizans İmparatorluğu'nun hâkimiyetine girdi. 589 yılında Sâsânîlerin eline geçtiyse de 591 yılında yapılan bir anlaşma ile

\footnotetext{
${ }^{5}$ Müverrih Vardan, Türk Fütühatı Tarihi (889-1269), Türkçe Çev. Hrant D. Andreasyan, Milli Mecmua Basımevi, İstanbul 1937, s. 232, 234; "Vartan Vekayinâmesi", Çev. Hasan Oktay, Ermeni Kaynaklarına Göre Türkler ve Moğollar, Selenge Yay., İstanbul 2007, s. 175; Aknerli Grigor, Okçu Milletin Tarihi, Yeditepe Yay., İstanbul 2012, s. 51; Genceli Kiragos, Moğol istilası 1220-1265, Çev. Mahmut Kemal Bey, Post Yay., İstanbul 2018, s. 136; Alican, a.g.t., s. 66.

6 "Sebasti Vakayinamesinden Bir Bölüm", A. G. Galstyan, Ermeni Kaynaklarına Göre Moğollar, Rusçadan Çev. Ilyas Kamalov, Yeditepe Yay., İstanbul 2005, s. 48 dn.170. Meyyâfârikîn isminin kökeni hakkında ayrıntılı bilgi için bkz. Alican, a.g.t., s. 35-41.

7 İbn Havkal, 10. Asırda İslâm Coğrafyası, Terc. Ramazan Şeşen, Yeditepe Yay., İstanbul 2014, s. 187; Ebü'l-Fidâ, Ebü'l-Fidâ Coğrafyası, s. 236; El-Ğamdi, a.g.m., s. 230.

8 Guy Le Strange, Doğu Hilafetinin Memleketleri, Çev. Adnan Eskikurt-Cengiz Tomar, Yeditepe Yay., İstanbul 2015, s. 156.

${ }^{9}$ El-Ğamdi, a.g.m., s. 230.

${ }^{10}$ Carole Hillenbrand, "Mayyafarikin", El2, Vol. 6, Leiden 1991, s. 929.
}

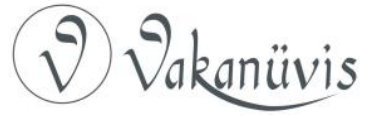


tekrar Bizans'a verildi. Şehir Müslümanların fethine kadar Bizans Imparatorluğu'nun hâkimiyetinde kaldı. ${ }^{11} \mathrm{~Hz}$. Ömer zamanında 19/640641'de Iyâz b. Ganm tarafından alındı. Belâzûrî, Meyyâfârikîn'in de içinde bulunduğu el-Cezîre bölgesindeki şehirlerin sulh yoluyla, topraklarının ise savaş ile alındığını kaydetmiştir. ${ }^{12}$ Daha sonra sırasıyla Emevî, Abbâsî, Hamdânî ve Mervânîlerin egemenliğinde kaldı. Mervânîler (372/983-478/1085) döneminde şehirde imar faaliyetleri önemli bir gelişme gösterdi. Surlar tamir edildi, dîni eserler, köprüler, sulama kanalları, hamamlar ve pazar yerleri yapıldı. Özellikle Nâsırü'ddevle (ö. 1061) zamanında şehir önemli bir refah seviyesine ulaştı. $^{13}$ 478/1085 yılından sonra Selçukluların, 512/1118 yılında Artukluların egemenliğine girdi. Artuklular zamanında başta Cuma Camii olmak üzere birçok eser tamir edildi ve yenileri yapıldı. Selahaddin Eyyûbî tarafından II. Şark Seferi (581-582/1185-1186) ile Eyyûbîlere bağlandı. Bu dönemde de yapılan imar faaliyetleriyle şehir gelişip büyümeye devam etti. ${ }^{14}$

\section{Moğolların Meyyâfârikîn Kuşatması}

\section{a. Meyyâfârikîn'in Moğollar Tarafından Kuşatılma Sebepleri}

1206 yılındaki kurultay kararı ile Cengiz unvanı alan Temuçin kısa sürede hâkimiyet alanını genişletti. ${ }^{15}$ Naymanları, Oyratları (Uyrat) ve Kırgızları itaat altına aldı. 1217 yılına gelindiğinde Pekin de dâhil olmak üzere Sarı Irmak'ın kuzeyindeki bölgeler Moğollar tarafından zapt edilmişti. ${ }^{16} 1218$ yılında meydana gelen Otrar Faciası, zamanın iki güçlü

\footnotetext{
${ }^{11}$ Hillenbrand, a.g.m., s. 930; Ahmet Savran, "Meyyâfarikîn", DiA, C. 29, s. 511; Alican, a.g.t., s. 81-89.

12 El-Belâzurî, Fütûhu'I-Büldân, Çev. Mustafa Fayda, Kültür Bakanlığı Yay., Ankara 1987, s. 251-252; Alican, a.g.t., s. 91-92; Savran, a.g.m., s. 511.

13 İbn'ül-Ezrak, Mervanî Kürtleri Tarihi, Çev. Mehmet Emin Bozarslan, Koral Yay., İstanbul 1975, s. 99-100, 115, 122, 128, 144.

${ }^{14}$ V. Minorsky, "Meyyâfârikîn", i.A., C. 8, MEB, İstanbul 1979, s. 199; Hillenbrand, a.g.m., s. 930.

${ }^{15}$ Abraham Constantin Mouradgea D'ohsson, Moğol Tarihi, Haz. Ekrem Kalan, IQ Kültür Sanat Yay., İstanbul 2014, s. 63-76; Mustafa Kafalı, "Cengiz Han", DiA, C. 7, s. 367.

16 Ahmet Temir, "Moğol veya Türk Moğol Hanlığı", Türkler Ansiklopedisi, C. 8, Yeni Türkiye Yay., İstanbul 2002, s. 416-433; Kafalı, a.g.m., s. 368.
}

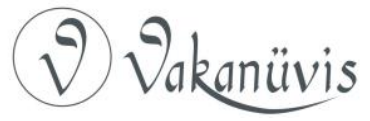


devleti olan Hârzemşahlar ile Moğolları karşı karşıya getirdi. Bu mücadeleden galip çıkan Moğollar, kısa zamanda Hârezmşahların topraklarının büyük bir kısmını ele geçirerek İran, Irak ve Anadolu'ya dayandılar. ${ }^{17}$ Asya'daki parçalanmışlık da Cengiz Han'ın hızlı bir şekilde ilerlemesini kolaylaştırdı.

Ögedey Han (1229-1241) ve Güyük Han (1246-1248) dönemlerinde Moğolların batıya doğru ilerleyişleri devam etti. Güyük Han'dan sonra hükümdar olan Mengü (Möngke) Han (1251-1259); İran'dan, Şam, Mısır, Anadolu ve Kafkasya'ya kadar olan yerleri kardeşi Hülagü’ye yarlık olarak verdi. ${ }^{18}$ Karakorum'dan hareket eden Hülagü 1 Zilhicce 653/1 Ocak 1256 tarihinde Ceyhun Nehri'ni geçip batıya doğru ilerledi. ${ }^{19}$ İsmâilîleri yenip reisleri Rükneddîn Hürşah'ı esir alarak Mengü Han'a gönderirken yolda öldürttü. ${ }^{20}$ Hülagü ikinci görevini yerine getirmek için Abbâsî Halîfeliği'nin üzerine yürüdü. Moğollar, Bağdad'ı alıp yakıp yıktılar. Hülagü, Halîfe Musta'sim'i (1242-1258) ve hânedan mensuplarının çoğunu 4 Safer 656/10 Şubat 1258 tarihinde öldürttü. ${ }^{21}$

17 Minhâc-i Sirâc el-Cûzcânî, Tabakât-ı Nâsırî (Moğol ístilasına Dair Kayıtlar), Çev. Mustafa Uyar, Ötüken Yay., Ankara 2016, s. 56-95; V.V. Barthold, Moğol İstilâsına Kadar Türkistan, Çev. Hakkı Dursun Yıldız, TTK, Ankara 1990, s. 422.

18 Reşîdüddin Fazlullah, Câmiu't Tevârih (ilhanlılar Kısmı), Çev. İsmail Aka vd., TTK, Ankara 2013, s. 13; Yahyâ b. Abdüllatif Kazvinî, Lübbû't-tevârîh, İntişârât-i Bünyâd-i Gûyâ, Tahran 1363, s. 230; Kadı Ahmed b. Muhammed-i Gaffarî-yi Kazvinî, Târîh-i Cihanara, Kitabfurûşi-yi Hâfız, Tahran 1963, s. 212; Abbas İkbal Aştiyânî, Târîh-i Moğol ez Hamle-yi Cengiz tâ Teşkîl-i Devlet-i Timûrî, Müesse-yi İntişârât-i Emîr-i Kebîr, Tahran 1986, s. 175-176; Şirin Beyânî, Moğulan ve Hükûmet-i ilhânî der irân, Tahran 1394, s. 104; Rene Grousset, Bozkır Imparatorluğu Atilla- Cengiz Han-Timur, Çev. M. Reşat Uzmen, Ötüken Yay., İstanbul 1999, s. 343.

${ }^{19}$ Alaaddîn Ata Melik Cüveynî, Tarih-i Cihan Güşa, Çev. Mürsel Öztürk, TTK, Ankara 2013, s. 500; Reşîdüddin Fazlullah, a.g.e., s.17; Şirin Beyânî, Moğulân ve Hükûmet-i ilhânî der irân, s. 103, 105.

20 Cüveynî, a.g.e., s. 592; Gregory Abû'l-Farac Bar Hebraeus (Ebü'l-Ferec ỉbnü'l-ibrî), Târîhu Muhtasari'd-Düvel, Terc. Şerafeddin Yaltkaya, TTK, Ankara 2011, s. 29; Vardan, a.g.e., s. 231; Reşîuüddin Fazlullah, a.g.e., s. 26; Berthold Spuler, Iran Moğolları, Çev. Cemal Köprülü, TTK, Ankara 2011, s. 61; Şirin Beyânî, Din û Devlet der Iran Ahd-i Mogul: Siyâset-i Hâricî Ilhânân der Cihan-ı İslâmî, C. 1, Merkez-i Neşr-i Dânişgâhî Tahran, Tahran 1370, s. 256; Aynı Müellif, Moğulân ve Hükûmet-i ilhânî der Irân, s. 129-132.

${ }^{21}$ Cüveynî, a.g.e., s. 592-602; Gregory Abû'l-Farac Bar Hebraeus (Ebü'l-Ferec İbnü'l-ibrî), Abû'l-Farac Tarihi, C. 2, Çev. Ömer Rıza Doğrul, TTK, Ankara 1999, s. 568-570; Vassaf, Tahrir-i Târîh-i Vassaf, Neşr. Abdu'l-Muhammed Âyetî, Bünyâd-i Ferheng-i İran, Tahran 1346, s. 13-24; Hamdullah Müstevfî-yi Kazvinî, Târih-i Güzide, Çev. Mürsel Öztürk, TTK,

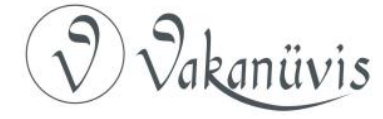


Hülagü, İsmâilîler ve Bağdad Abbâsî Halîfeliği'ni ortadan kaldırdıktan sonra üçüncü görevi olan Suriye ve Mısır'ı almak için harekete geçti. Parçalanmış durumda olan bölgenin yerel yöneticilerine teslim olmaları için mektuplar gönderdi. İsteğini yerine getirmeyenlere karşı ordusunda Hristiyan Ermeniler ve Gürcüler de olmak üzere harekete geçti. Hülagü'ye Suriye'nin Akdeniz kıyısındaki Haçlı Krallıkları da yardım ettiler. $^{22}$

Eyyûbîler, Selâhaddîn Eyyûbî'nin ölümünden sonra altı parçaya ayrılmışlardı. Moğollar Ön Asya'ya geldikleri sırada 639/1241 yılında Eyyûbîler'in Kuzey Mezopotamya (Meyyâfârikîn) adıyla anılan kolunun emîri Melik Muzaffer Şehâbeddîn Gâzi (617-642/1220-1244) idi. Şehâbeddîn Gâzi, Selâhaddîn Eyyûbî'nin kardeşi Melik Âdil'in yeğeniydi. Moğollar ona elçi göndererek Meyyâfârikîn'in etrafındaki surların yıkılarak şehrin teslimini istemişlerse de Şehâbeddîn Gâzi onları oyalamayı ve tehlikeyi atlatmayı başarmıştı. ${ }^{23}$

Şehâbeddîn Gâzi'nin ölümünden sonra geride el-Melik el-Efdal Nûreddîn, el-Melik el-Kâmil ve el-Melik el-Eşref Mûsâ adlarında üç oğlu kaldı. El-Melik el-Efdal (642-658/1244-1260 ) babasından sonra hükümdar olduysa da kısa süre sonra öldü. Yerine el-Kâmil geçti. ${ }^{24}$

Moğolların Baycu Noyan komutasında harekete geçtiğini duyan elKâmil, kardeşi el-Eşref Mûsâ'yı Baycu Noyan'ı durdurması için Batu Han'a gönderdi. El-Eşref Mûsâ, Batuhan'dan el-Kâmil'in Mengü Han'ın yanına gitmesi şartıyla ona dokunulmayacağına dair mektup getirdi. Mûsâ Meyyâfârikîn'e döndügünde şehir Moğollar tarafından kuşatılmıştı. el-Kâmil, Batu Han'dan getirilen mektubu Baycu Noyan'a gönderince o da kuşatmayı kaldırdı. ${ }^{25}$ El-Kâmil, 650/1252-1253 yılında

Ankara 2018, s. 478; Vardan, a.g.e., s. 232; Celâleddîn Suyûtî, Halifeler Tarihi, Arapçadan Çev. Onur Özatağ, Kabalcı Yay., İstanbul 2001, s. 478; Ebû'l-Fidâ, Târîhu Ebî'lFidâ el-Müsemmâ el-Muhtasar fí Ahbâri'I-Beşer, C. 2, Tahkik Mahmûd Deyyûb, Beyrut 1997, s. 302-303; Benâketî, Târîh-i Benâketî (Ravzât ûî'l-Elbâb fî Ma'rifeti't-Tevârîh ve'lEnsâb), Ed. Ca'fer Şi'ar, Tahran 1348, s. 415-419; İbni Tagrıberdi, En-Nücûmu'z-Zâhire (Parlayan Yıldızlar), Arapçadan Çev. Ahsen Batur, Selenge Yay., İstanbul 2013, s. 30-31. ${ }^{22}$ Abdulkadir Yuvalı, ilhanlı Tarihi, Bilge Kültür Sanat Yay., İstanbul 2017, s. 168.

23 Minorsky, a.g.m., s. 199; Hillenbrand, a.g.m., s. 930-931.

${ }^{24}$ Claude Cahen, "XIII. Asır Ortalarında Cezire (İzzeddin b. Şeddada Göre)", Çev. Neşet Çağatay, Ankara Üniversitesi Ilahiyat Fakültesi Dergisi, C. 2, S. 4, (Ankara 1952), s. 100. ${ }^{25}$ Cahen, a.g.m., s. 101.

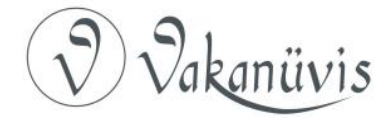


yanında kıymetli hediyelerle birlikte Moğolların Büyük Hanı Mengü’nün yanına giderek bağıı ı̆ını bildirdi. Mengü Han onu iyi karşıladı ve başta hil'at olmak üzere çeşitli hediyeler verdi. El-Kâmil, 1257 tarihinde ülkesine döndü. ${ }^{26}$ Görüldüğü gibi Hülagü Ön Asya'ya geldiği sırada, Eyyûbîler'in Kuzey Mezopotamya (Meyyâfârikîn) adıyla anılan kolu, Melik I. Âdil Şehâbeddîn'in oğlu tarafından bir devlet hatta beylik olarak yönetilmekteydi. ${ }^{27}$

El-Kâmil'in ülkesine dönmesinden kısa bir süre sonra Moğollar tekrar Meyyâfârikîn'i almaya karar verdiler. Hülagü'nün Meyyâfârikîn'i almak istemesinin birçok sebebi vardı.

a. Hülagü Bağdad'ı almak için yola çıktığı sırada el-Kâmil'in de 7 bin atlı ve 20 bin piyâde ile Bağdad kapısına gelip kendisine yardım etmesini istedi. El-Kâmil bu kadar askerinin olmadığını, 2-3 bin süvâri ve 5-6 bin piyâde ile yardıma gelebileceğini bildirdi. Bu söz üzerine Hülagü süvâri talebini daha da arttırdı. El-Kâmil de cevabında ısrar edince, Hülagü Semerkand'ın tanınmış kişilerinden ve aynı zamanda da Müslüman olan vezirine el-Kâmil'in kendilerine isyan edeceğini, onun öldürülmesi gerektiğini gizlice söyledi. Vezirin el-Kâmil ile arası iyi olduğundan durumu ona bildirdi. El-Kâmil ertesi gün Hülagü’nün yanına gidip av için izin isteyerek yetmiş has süvârisi ile hızlıca onun yanından ayrıldı ve yedi günde Meyyâfârikîn'e ulaştı. Moğol şahnelerini alınlarından, el ve ayaklarından duvara mıhladı. Hülagü, el-Kâmil'i yakalamaları için arkasından birlik gönderdiyse de bu birlik ona yetişemedi. Moğolların Bağdad kuşatması sırasında Hülagü’ye yardım göndermek istemeyen elKâmil, Halîfe Musta'sim'e yardım gönderdi. Fakat hilâfete yardım olarak gönderilen süvâri birliği ulaşamadan Moğollar Bağdad'ı aldıkları için

\footnotetext{
${ }^{26}$ Cûzcânî, a.g.e., s. 166; Cahen, a.g.m., s. 101; Dashdondog Bayarsaikhan, The Mongols and the Armenians (1220-1335), Vol. 24, Ed. Michael R. Drompp Devin DeWeese, Leiden-Boston 2011, s. 134. Cûzcânî, el-Kâmil ile Mengü Han'ın görüşmesini şu şekilde kaydetmiştir: "Melik Şehabü'ddîn Gazi'nin oğlu Melik el-Kâmil, Mengü Han'ın huzuruna gitti ve ondan özel hil'at aldı. Bunun sebebi şu idi: Hülagü içki meclisinde Şehabü'ddîn Gazi'nin oğluna şarap ikram etti. $O$, imtina ederek içmedi. Mengü Han içmemesinin sebebini sordu. El-Kâmil, o (şarap) islâmiyet'e göre haramdır ve ben dinime karşı gelemem" cevabını verdi. Bu söz Mengü Han'ın hoşuna gittiğinden giymiş olduğu elbiseyi ona verip taltif etti. Cûzcânî, a.g.e., s. 166. Cûzcânî; el-Kâmil'in Hülâgü ile birlikte döndüğünü kaydetmiştir. Cûzcânî, a.g.e., s. 166-167.
}

27 Cûzcânî, a.g.e., s. 166-167; Abbas İkbal, a.g.e., s. 341.

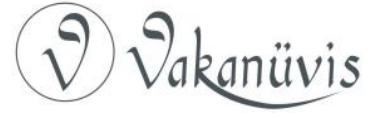


birlik geri döndü. ${ }^{28}$ El-Kâmil'in bu davranışı Meyyâfârikîn'i Hülagü’nün almak istemesinin en önemli sebeplerinden biridir.

b. Abû'l-Farac, Moğolların şehri kuşatmasının diğer bir sebebini; Bağdad'ın alınmasından sonra Eşref Bidlisli adında birinin, Moğol hanından yarlıg getirmekte olan görevliyi öldürdükten sonra el-Kâmil'in yanına giderek onu Moğollara karşı kışkırtması ve bu bilginin Hülagü’ye gelmiş olması olarak kaydetmiştir. ${ }^{29}$

c. Kiragos'a göre Bağdad'ın Moğollar tarafından alınmasından sonra Hülagü, oğlu ve askerlerinin bir kısmını toplayıp íligya (ilkan) Noyan ${ }^{30}$ ile birlikte Fırat Nehri civarına keşif gezisine gönderdi. Meyyâfârikîn'in yanından geçerken oranın halkı, İligya Noyan'ı davet edip kendilerine boyun eğmeyi kabul ettiklerini ve onlara asker ve haraç vereceklerini söylediler. El-Kâmil ise tam tersini düşündügü için askerlerini toplayarak Moğolları takip etti. Birkaçını öldürdükten sonra şehre kapanarak burayı savunmaya uygun bir hale getirdi. ${ }^{31}$

d. Moğolların el-Kâmil'e yönelttikleri suçlamalardan birisi de rivâyete göre onun, ülkesine Moğol kimliği ile girmiş olan bir Yakubî Hristiyan'ı çarmıha gerdirtmesiydi. ${ }^{32}$

e. Hülagü'nün daha önce el-Kâmil'den Diyarbakır Kalesi'nin surlarını yıkmasını istediği halde onun, burayı yıkmayıp Türkiye Selçuklu Sultanı'na vermesi kuşatmanın bir başka sebebiydi. ${ }^{33}$

\footnotetext{
${ }^{28}$ Cûzcânî, a.g.e., s. 167; Vassaf, a.g.e., s. 25; Mîrhând, Târîh-i Ravzâtu's-Safâ fî Sîreti'lEnbiyâ ve'l-Mülûk ve'l-Hulefâ, C. 5, Neşr. A. Pervîz, Tahran 1339, s. 258; Dashdondog, a.g.e., s. 134.

${ }^{29}$ Abû'l-Farac, Abû'l-Farac Tarihi, C. 2, s. 572.

30 İsmi illigya veya ilgay Noyan olarak çeşitli şekillerde telaffuz edilen IIlkan Noyan, Celâyir kabilesinden olup Cengiz Han döneminin komutanlarından Cücü Tarmalan'ın oğludur. Illkay Noyan, Hülagü'nün önemli komutanlarından biridir. Bağdad, Suriye ve Anadolu'daki faaliyetlerde adı sık sık geçmektedir. 1259'da Bağdad'dan Meyyâfârikîn'e gelmiştir. El-Kâmil'i Hülagü'nün huzuruna o getirmiştir. 1265'te Alıncak Noyan'ın yerine Anadolu komutanı olarak atanmıştır. Bkz. Mustafa Akkuş, "Hûlagû Han Döneminde Anadolu'da Görev Yapan Moğol Komutanları", Necmettin Erbakan Üniversitesi Sosyal Bilimler Enstitüsü Dergisi, S. 9, (Konya 2018), s. 163.

${ }^{31}$ Genceli Kiragos, a.g.e., s. 136.

${ }^{32}$ Abû'l-Farac, Târîhu Muhtasari'd-Düvel, s. 37; Grousset, a.g.e., s. 343.

${ }^{33}$ Cahen, a.g.m., s. 103.
}

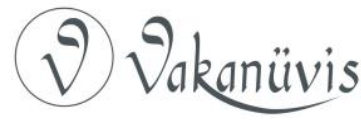


Moğolların Meyyâfârikîn'i kuşatmalarının asıl sebebi ise Mezopotamya'nın üst kısımlarını kontrol altına almak istemeleriydi. Bölgenin büyük bir bölümünü ele geçiren Moğolların burayı kendi kaderine bırakmaları mümkün değildi.

\section{b. Meyyâfârikîn'in Moğollar Tarafından Kuşatılması ve Alınması}

Hülagü’nün emriyle, oğlu Yaşmut ${ }^{34}$, Meyyâfârikîn'i ele geçirmek için harekete geçti. ${ }^{35}$ Yaşmut ile birlikte büyük emîrlerden illigya Noyan ve Suntay da Hülagü'nün emriyle yola çıktı. ${ }^{36}$ Yaşmut, el-Kâmil'e elçi gönderip, yanına hediyeler alarak Hülagü'nün huzuruna gitmesini söyledi. El-Kâmil ile görüşen elçi, Yaşmut'un isteklerini iletti ve onu itaate ve il olmaya davet etti. El-Kâmil; Moğolların Bağdad'ı aldıkları kadar kolay bir şekilde Meyyâfârikîn'i alamayacaklarını, kendisinin sonuna kadar onlarla mücadele edeceğini söyledi. ${ }^{37}$ Elçi, el-Kâmil'e

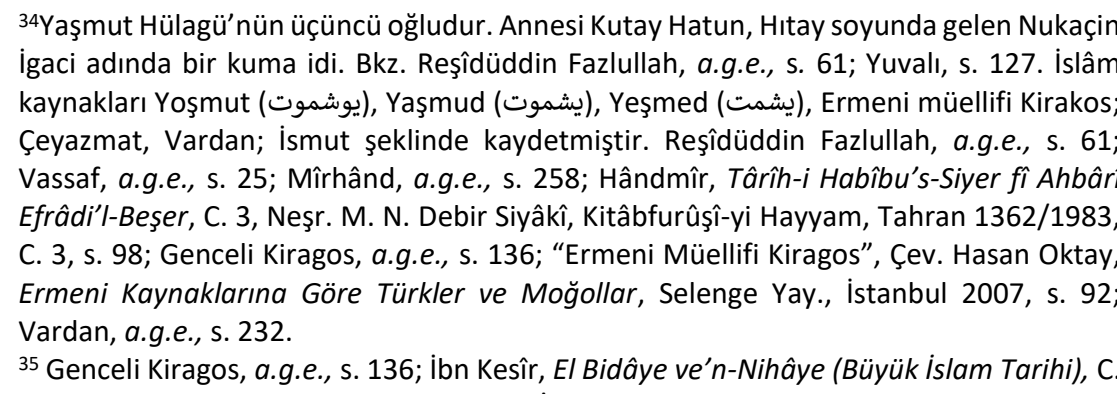
13, Çev. Mehmet Keskin, Çağrı Yay., İstanbul 1994, s. 381; Vassaf, a.g.e., s. 25; Reşîuüddin Fazlullah, a.g.e., s. 60-61; Mîrhând, a.g.e., s. 258; Hândmîr, a.g.e., s. 98; Süleyman Savcı, Silvan Tarihi (Mafarkın Âbide ve Kitabeleri), Diyarbakır Matbaası, Diyarbakır 1956, s. 37; J. A. Boyle, "Dynastic and Political History of The II-Khāns", Cambridge History of iran, Vol. 5, (Cambridge 1968), s. 350; Abbas ikbal, a.g.e., s. 341;Ömer Subaşı, Gürcü Moğol ilişkisi Güney Kafkasya 1220-1346, Kitabevi Yay., İstanbul 2015 s. 89. Ebû'l-Fidâ Hicrî 656 yılında kuşatmanın başladığını kaydetmiştir. Bu bilgi de doğrudur. Çünkü Yaşmut, kış yaklaştığı için ilk kuşatmayı kaldırıp baharda yeniden kuşatmaya başlamıştır. Ebû'l-Fidâ, Târîhu Ebî'l-Fidâ, s. 313.

${ }^{36}$ Reşîdüddin Fazlullah, a.g.e., s. 60; Mîrhând, a.g.e., s. 258; Hândmîr, a.g.e., s. 98. Reşîdüddin Hülagü'nün daha Diyarbakır'a gelip Cezîre'yi aldığı sırada Yaşmut'un oğlunu Suntay Noyan ile birlikte Meyyâfârikîn'i alması için tayin ettiğini kaydetmiştir. Reşîuüddin Fazlullah, a.g.e., s. 53.

${ }^{37}$ Reşîdüddin Fazlullah, a.g.e., s. 61; "Ermeni Müellifi Kiragos", s.92; Mîrhând, a.g.e., s. 259; Hândmîr, a.g.e., s. 98; Jeremiah Curtin, The Mongols A History, Barton 1908, s. 273; Laura Venegoni, "The Political Backround of the Mongolian Conquest and Hülagü's West

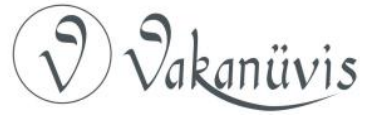


inadının bir sonuç vermeyeceğini bu nedenle şehri Moğollara teslim etmesinin kendisi için daha iyi olacağını söyledi. El-Kâmil, elçiye; Hülagü'nün önce söz verdiğini sonradan İsmâilî lideri Hürşah, Abbâsî Halîfesi Musta'sim ve bölgedeki diğer yönetici Hüsâmüddevle başta olmak üzere pek çok kişiyi öldürdüğünü bu nedenle ona güvenmediğini söyledi. ${ }^{38}$ Elçi, el-Kâmil'in bu olumsuz sözlerini Yaşmut'a söyledi. ${ }^{39}$

El-Kâmil; hazinesinde bulunan altın ve gümüş başta olmak üzere bütün değerli eşyaları, hububatı, yiyecek içecek ne varsa hepsini askerlerine ve şehir halkına dağıttı. Onlara; mal hırsı yüzünden Abbâsî Halîfesi'nin beş yüz yıllık hânedanı feda ettiğini, kendisinin Halîfe Musta'sim gibi dünya malına tamah etmeyeceğini, malın mülkün bir öneminin olmadığını söyledi. El-Kâmil'in bu davranışları bütün şehir ahalisinin kendisi ile birlikte direniş heyecanına kapılarak Moğol ordusunu yenme ümidi ile kenetlenmesini sağladı. ${ }^{40}$ Meyyâfârikîn, Müslümanların fethine kadar, Hristiyanlar tarafından Şehitler Şehri olarak anılıyordu. Şehir güçlü surlarla çevrili idi. ${ }^{41}$ El-Kâmil en çok da bu surlara güveniyordu.

Elçilerin gelip gitmesi sonuç vermeyince Moğollar şehri kuşattılar. Ancak da kış yaklaştığı için geri çekildiler. Illkbaharda geri gelerek kuşatmayı tekrar başlattılar. ${ }^{42}$ Hülagü, Prens Çağatay ismindeki

Conquest (1256-1260)", Hacettepe Üniversitesi Türkiyat Araştırmaları Enstitüsü Dergisi, S. 6, (Ankara 2007), s. 37; Cahen, a.g.m., s. 102.

38 Cüveynî, a.g.e., s. 592; Reşîdüddin Fazlullah, a.g.e., s. 61; Mîrhând, a.g.e., s. 258; Hândmîr, a.g.e., s. 99. Reşîdüddîn; el-Kâmil'in, elçinin teslim ol çağrısına verdiği cevabı şu şekilde kaydetmiştir: "Şehzâdenin (Yaşmut'un) soğuk demiri dövmemesi ve mümkün olmayan bir şeyi benden beklememesi gerekiyor. Çünkü sizin sözüne itimat yoktur. Ben sizin yumuşak sözlerinize aldanmayacağım. Moğol ordusundan endişelenmem. Ömrüm oldukça kılıç sallayacağım. Çünkü Hürşah, Halîfe Hüsâmeddîn Akke ve Tâceddîn-i Erbil'e söz verip sözünde durmayan o babanın oğlusun. Özellikle de Melik Nasr emân için size geldi. Sonunda göreceğini gördü. Mutlak benim de sonum onlar gibi olacak." Reşîdüddîn Fazlullah, a.g.e., s. 61.

${ }^{39}$ Reşîdüddîn Fazlullah, a.g.e., s. 61.

${ }^{40}$ Reşîuüddîn Fazlullah, a.g.e., s. 61; Mîrhând, a.g.e., s. 258; Hândmîr, a.g.e., s. 98.

${ }^{41}$ Aknerli Grigor, a.g.e., s. 53.

${ }^{42}$ Cahen, a.g.m., s. 103. Kuşatmanın ne zaman başladığı ile ilgili kesin bir bilgiye ulaşmak çok zordur. 15 Zilkaade 655/24 Kasım 1257 yılının yanında, sadece 656 yılı da kaydedilen tarihlerden birisidir. Kaynakların büyük bir kısmının kuşatmanın iki yıl sürdüğünü kaydetmeleri dikkate alındığında ve Reşîüddîn'in 657/1259 yılını, Kiragos'un ise 1260 yılının ocak ayını el-Kâmil'in öldürüldüğü tarih olarak kaydetmelerine bakıldığında (bu

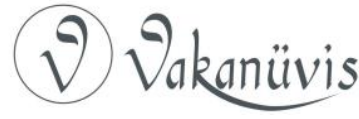


komutanı ile Gürcü asıllı Hristiyan Prensi Hasan (Broş)'ın refakatinde büyük bir kuvveti Meyyâfârikîn'e gönderdiğini söyleyerek şehrin her taraftan kuşatılıp hiç kimsenin girip çıkmamasını emretti. Moğollar kuşatma sırasında şehrin ortasından geçen nehrin yatağını değiştirerek direnen halkı zor durumda bıraktılar. ${ }^{43}$

Ermeniler, Gürcüler ve Süryaniler başta olmak üzere Doğu Hristiyanlarının büyük bir bölümü Meyyâfârikîn kuşatmasında Moğollara destek verdiler. Bu desteklerinin sebeplerinden birisi elKâmil'in kendi ülkesine gelen Yakubî bir Hristiyan'ı öldürtmesiydi. Bu durum onların Müslümanlara olan kinlerini daha da arttırdı. Bu Doğu Hristiyanları, Moğollarla bir olup Müslümanlara karşı bir nevi Haçlı Seferi yürütüyorlardı. ${ }^{44}$ Kuşatmaya Gürcü Hasan Broş ile birlikte Büyük Prens Gregor'un oğlu Haçenli Sevata adında bir Ermeni prensi de katılmıştı. Fakat prens kuşatma esnasında öldürüldü. ${ }^{45}$ Moğolların tarafında Mardin Emîri Melik Muzaffer ve Musul Emîri Bedreddîn Lü'lü'nün iki oğlu gibi Müslüman müttefikler de vardı. ${ }^{46}$ Musul hükümdarı Bedreddîn Lü'lü Moğollara itaat etmişti. ${ }^{47}$ Daha önceden elKâmil ile anlaşmazlık içinde olduğundan, şimdi Moğollara yardım etmeyi

\footnotetext{
iki kaynağın verdiği tarihler birbirine çok yakındır) kuşatmanın 655/1257 yılının KasımAralık aylarında yani Zilkaade 655 'te başlaması mantıklı görünmektedir. Ebû'l-Fidâ'nın kuşatmanın tarihini 656 yılı olarak kaydetmesi ise kış yaklaştığı için 655 Kasım-Aralık aylarında kuşatmayı kaldırıp 656 yılı baharında yeniden geldikleri tarihi göz önünde bulundurmasın dolayı olabilir. Bu tarih daha mantıklı görünmektedir. Ancak Meyyâfârikîn kuşatmasının bir sebebinin de el-Kâmil'in Moğollara karşı Abbasî Halifeliği'ne yardım göndermesi olduğu göz önüne alındığında kuşatmanın Bağdad'ın Moğolların eline geçtiği tarih olan Safer 656/Şubat 1258 tarihinden daha sonra olması gerekir kanaatindeyiz. Reşîdüddîn Fazlullah, a.g.e., s. 63; Genceli Kiragos, a.g.e., s. 138; Ebû'l-Fidâ, Târihu Ebî'l-Fidâ, s. 313.

${ }^{43}$ Genceli Kiragos, a.g.e., s. 137; Ermeni Müellifi Kiragos, s. 93.

${ }^{44}$ Grousset, a.g.e., s.343.

${ }^{45}$ Vardan, a.g.e., s. 234; Dashdondog, a.g.e., s. 135.

${ }^{46}$ Reşîuüddîn Fazlullah, a.g.e., s. 61; Cûzcânî, a.g.e., s. 170-171; Cahen, a.g.m., s. 102; Grousset, a.g.e., s. 343.

47 Ahmed b. Ali Makrizî (ö. 845/1442), Kitâbü's-Sülûk fí Marifeti Düvel el-Mülûk, C. 1, Bölüm 2, Yay. M. Zaide, Kâhire 1936-38, Türkçe Tercüme Zakir Kadiri Ugan, TTK Tercüme Eserler Bölümü Yayınlanmamış Daktilolu Tercüme Yazmalar Kısmı, s. 129.
}

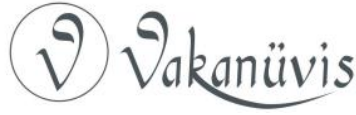


çıkarları açısından uygun bularak Meyyâfârikîn kuşatması sırasında oğlunun komutasında onlara destek kuvveti gönderdi. ${ }^{48}$

Moğollar her basamağında altı kişinin yan yana sığdığı altı yüz merdiveni şehrin surlarına kurdular. El-Kâmil tarafında savaşmakta olan Laçin adlı ileri gelen birisinin ihaneti ile de bir gece şehre girmeyi başardılar. Ancak kalede Moğollara karşı savaşmakta olan Hısn-ı Keyf emîrinin bir adamı onları iki duvar arasına sıkıştırdı. Olayı haber alan elKâmil de bizzat mücadeleye dâhil oldu. Çok kayıp veren Moğollar ölülerini dahi alamadan kaçtılar. ${ }^{49}$

Yaşmut üç ay boyunca Meyyâfârikîn Kalesi'ni kuşattı. El-Kâmil, halkı ile bir bütün olarak direndi. İki tarafın askerleri de kahramanca savaştılar. Moğollar çok büyük kayıplar verdiler. Seyfeddîn Levkili (Leviklî, Lerkili, Erkelî) ve Anber-i Habeşî isimli iki yiğidin birçok Moğol askerini öldürmesi ile savaş ateşi daha da alevlendi. Bu iki kahraman şehre gelip mücadeleye surlarda devam ederek Moğollara ok atmaya başladılar. İkinci gün atlı olarak tekrar dışarı çıkıp on Moğol askerini öldürdüler. Ölenler Moğolların en şöhretli savaşçılarıydı. Üçüncü günde de Seyfeddîn Leviklî ve Anber-i Habeşî’nin kahramanlıkları aynı şekilde devam etti. Dördüncü gün bu iki yiğitle savaşması için Kerec'den zamanın Rüstem-i Destan'ı diye anılan bir yiğit Moğolların tarafına geldi. Fakat o da mücadeleler sırasında öldü. İki yiğit çok cesurca mücadelelerini sürdürüyorlardı. Bir rivâyete göre bunlar beyaz elbiseler giymiş ve sarık takmış vaziyette kaleden çıkıp Allah'ın yardımı ile düşman askerine saldırıyorlardı. Moğolların hiçbir oku, kılıcı ve mızrağı bu beyaz giysili atlılara zarar veremiyordu. Kuşatma sırasında Moğolların kayıpları günden güne artmaktaydı. Kaynaklar bu mücadeleler sırasında yaklaşık 10 bin Moğol askerinin öldüğünü kaydetmişlerdir. ${ }^{50}$

Kuşatmanın başından beri şehirde büyük bir mancınık vardı. Bu mancınık ile Moğollara çok büyük taşlar fırlatılıyorlardı. Moğollar bu

48 Dashdondog, a.g.e., s. 134; El-Kâmil ile Bedreddîn Lü'lü arasındaki anlaşmazlık hakkında bkz. Cahen, a.g.m., s. 99-101.

${ }^{49}$ Cahen, a.g.m., s. 103.

50 Cûzcânî, a.g.e., s. 169; Reşîdüddin Fazlullah, a.g.e., s. 61; Mîrhând, a.g.e., s. 258. Hândmîr, bu iki yiğidin el-Kâmil'i çok sevdiklerini, bunların kahramanlıklarının yanında Rüstem ve İsfandiyâr'ın hikâyesinin önemsiz kaldığını kaydetmiştir. Handmîr, a.g.e., s. 99.

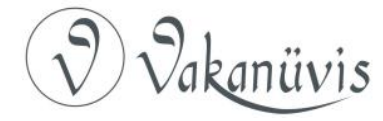


mancınığın attığı taşlardan kurtulmanın yollarını aramaya başladılar. Hem el-Kâmil'in mancınığı ile baş etmek hem de şehri ele geçirebilmek için Musul'dan müttefikleri Bedreddîn Lü'lü'nün mahir bir mancınık ustasını ve mancınığını getirip şehrin karşısına kurdular. Böylece elKâmil ile Bedreddîn Lü'lü'nün en iyi iki mancınık ustası karşı karşıya geldi. Mancınıkların attığı taşlar adeta havada birbirine isabet ediyor ve ufalanıyordu. Kalenin içinden ve dışından bunu görenler hayretler içinde kalıyorlardı. Ancak daha ilk gün kaleden atılan neft ile Moğolların Musul'dan getirdikleri mancınık yakıldı. Şehir halkı kararlı bir şekilde mücadelesini sürdürüyordu. Moğolların Meyyâfârikîn şehrinin ortasından geçen nehrin yönünü değiştirmelerine ve halkı susuz bırakmalarına rağmen direniş daha da kararlı bir şekilde devam ediyordu. ${ }^{51}$

Kaynaklar, kuşatma sırasında meydana geldiğini iddia ettikleri ilginç olaylardan da bahsetmişlerdir. Bu ilginç olaylardan bahsedenlerden birisi de Cûzcânî'dir. O, kuşatma sırasında Meyyâfârikîn'de şu kerâmetin meydana geldiğini kaydetmiştir: Melik Bedreddîn Lü'lü Musulînnin oğlu, Hülagü'nün oğlunun ordusundaydı. Savaşlar Moğolların mahvını ve Meyyâfârikîn gazilerinin zaferini müşahede ediyordu. O (Lü'lü'nün oğlu) bu duruma şaşa kalıyor ve semâvî yardıma hayret ediyordu. Hatta bir gece Hâce-i Âlem Sallallâhû Aleyhi ve Sellem'in mübârek cemâlini rüyâsında gördü. Meyyâfârikîn kalesinin burcunun üzerinde duruyor, mübârek kaftanını kalenin etrafına çekmişşöyle diyordu: "Bu kale Hüdâyı Teâlâ'nın ve ben Muhammed'in nübüvvetinin korumasındadır." Bedreddîn Lüllü'nün oğlu bu rüyânın korkusu ile uyandı. Tüm gün bu tuhaf rüyânın tâbirinin ne olduğunu düşündü. Üç gece aynı rüyâyı gördü. Büyük korku ve dehşet yüzüne ve kalbine hâkim oldu. Üçüncü gün kendi hasları ile av bahanesi ile toplanıp küffâr ordugâhından ayrıldı ve kendi ülkesine gitti. Babası durumu öğrendiğinde; "Beni ve ülkemi yokluğa ve

51 Genceli Kiragos, a.g.e., s. 137; Reşîuüddin Fazlullah, a.g.e., s. 62; Cûzcânî, a.g.e., s. 169; Mîrhând, a.g.e., s. 259; Handmîr, a.g.e., s. 99; Curtin, a.g.e., s. 273; Ayşe D. Erdem Kuşçu, "Illhanlı Devleti'nin Kuruluşu ve Memluklularla IIlk Teması", Türkler Ansiklopedisi, C. 8, Yeni Türkiye Yay., Ankara 2002, s. 366; Uyar, İlhanlıların beraberlerinde getirdikleri mancınık teknolojisini geldikleri coğrafyaya uyarlamak zorunda kaldıklarını kaydetmiş ve bu konuya da Meyyâfârikîn kuşatması için Bedreddîn Lü'lü'den getirilen mancınığı örnek vermiştir. Mustafa Uyar, ilhanlı (iran Moğolları) Devleti'nin Askerî Teşkilatı, TTK, Ankara 2020, s.153.

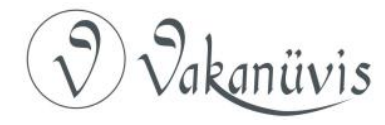


mahvoluşluğa attın. Bu hareketle itaatsizliği neden yaptın? Seni hiçbir şekilde yanımda tutmam diye haber gönderdi. Bedreddîn Lü'lü'nün oğlu, babasına haber göndererek: Ben Muhammed Resûlullah ile savaşamam diyerek rüyâsını ona anlattı. Başka bir tarafa gitti. Bu tarihten sonra onun ve babasının hakkında başka bir şey bilinmemektedir. ${ }^{52}$

Hülagü, şiddetli direniş nedeniyle kalenin alınamadığını haber alınca Uruktu'yu ${ }^{53}$ bir ordu ile illgay Noyan'ın yardımına gönderdi. Uruktu sarhoş bir vaziyette kaleye yaklaştığı sırada iki yiğit süvâri dışarı çıkıp Moğol ordusunu dağıttılar. Bu mücadeleler sırasında ilkan Nogay'a saldırıp attan düşürdülerse de Moğol süvârileri onu tekrar atına bindirdiler. Bu sırada Seyfeddîn Levkili ve Anber-i Habeşî her gün dışarı çıkıp birkaç kişiyi öldürerek düşmana kayıplar verdirmeye devam ediyorlardı. ${ }^{54}$

\footnotetext{
52 Cûzcânî, a.g.e., s. 169-170.

53 illkan Noyan'ın sekizinci oğlu olup adı ilk kez Hülagü’nün Bağdad'ı alması sırasında duyulmuştur. Hülagü Bağdad'ın istilası için 1257 yılında Tebriz'den hareket ettiği sırada Uruktu Noyan da onun yanındaydı. İki yıl boyunca Konya bölgesinde görev yapmış, 1277 yılında Memlûk Sultanı Baybars'a karşı görevlendirilmiştir. Nisan 1277 yılında Elbistan ovasında yapılan savaşta Moğol ordusunun büyük kısmı ve birçok Moğol komutanı ile birlikte Uruktu Noyan da öldürülmüştür. Bkz. Akkuş, a.g.e., s. 168.

${ }^{54}$ Reşîdüddin Fazlullah, a.g.e., s. 62. Başka kaynaklarda yer almayan ancak Cûzcânî'nin verdiği bilgiye göre Hülagü, oğluna gönderdiği bir ulak ile: "Ben Bağdad'ı bir haftada aldım. Sen ise küçük bir kaleyi uzun bir müddettir alamadın." dedi. Oğlu Yaşmut ona şu cevabı verdi: "Sen Bağdad'ı hile ile aldın. Benim ise burada kılıç sallamam gerekiyor. "Her gün bir miktar asker helak oluyor. Burayı Bağdad ile kıyas etmemek gerek." Yaşmut'un cevabı babasına ulaştığında, babası yemin ederek: "Ben o kaleyi üç günde alırım. Gözüme gözükmeyesin. Yoksa seni mutlaka öldürürüm." dedi. Meyyâfârikîn tarafına geldi ve savaş tekrar şiddetlendi. Cûzcânî, s. 169. Yine Cûzcânî́nin rivayetine göre daha önce olduğu gibi birkaç beyaz giysili ve sarıklı adam dışarı çıkıp yaklaşık üç yüze yakın Moğol askerini öldürdüler. Üç gün boyunca çetin savaşlar oldu. Bu süreç içinde bin Moğol askeri daha öldü. Hülagü, "Bu kale Tengirinindir. Şimdi sizi özgür bırakıyorum ama bir isteğim var. Onların nasıl insanlar olduğunu görmem için beyaz giysili süvârileri bana gösterin" dedi. Mesaj kaleye ulaştığında onlar büyük bir yeminle; "Siz nasıl onları bilmiyorsanız biz de onları tanımıyoruz. Onların kim olduklarını bilmiyoruz dediler. Hülagü, o halde Tengri rızası için size bin at, bin deve, bin koyun sadaka veriyorum. Bunları almaları için adamlarınızı dışarı gönderin" dedi. Kale halkı; "bizim senin sadakana ihtiyacımız yok ve kimseyi dışarı göndermeyeceğiz" dedi. Cûzcânî, a.g.e., s. 169-170.
}

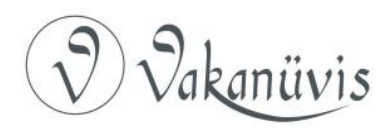


Hülagü, Meyyâfârikîn hâkîmi el-Kâmil'in çok cesur olduğunu duydu. Argûn Noyan ${ }^{55}$ ile Yaşmut'a bir haber gönderdi. Haberde; şehrin alınması için acele edilmemesini, savaşı durdurmalarını, şehirdeki erzakları tükenene kadar kuşatma halinde beklemelerini, erzakları biten şehir halkının zor durumda kalıp teslim olacağını söyledi. ${ }^{56}$

Kuşatma iki yıl boyunca bu şekilde devam etti. Sonunda şehirde yiyecek içecek tükendi. Kıtlık bütün şiddeti ile kendini gösterdi. Abû'lFarac; Meyyâfârikîn ahalisinden olup alevli bir fırının içinden çıkan yanmış bir odun parçasından farksız bir hale gelen Ardu isimli birisinin kendisine şunları anlattığını kaydetmiştir: "Bir gün çocuklarımla birlikte etle kaynatılmış buğday yemeğini özledim. Bu bir tencerelik yemeği beş yüz Hristiyan zuze'sine çok büyük güçlüklere katlanarak mal edebildim."157 Makrizî ise şehirdeki insanların açlıktan pabuçlarını yediklerini kaydetmiştir. ${ }^{58}$ Kuşatma sürdükçe kıtlığın şiddeti daha da artıyordu. Bir süre sonra halk açlıktan fare, kedi ve köpek başta olmak üzere murdar hayvanları yemeye başladı. Aknerli Grigor kıtlık esnasında bir eşek başının fiyatının otuz dirheme kadar yükseldiğini kaydetmiştir. ${ }^{59}$

Kale halkı yazın sıcağında zor günler yaşamasına rağmen yine de şehri teslim etmedi ve direnmeye devam etti. ${ }^{60}$ Kuşatmanın devam etmesi yiyecek kıtlığının şiddetini o kadar arttırdı ki insanlar birbirlerinin etlerini yemeye başladılar. Reşidüddîn Fazlullah; Moğollara karşı

55 Argûn Noyan (Argûn Aka): Mengü Han'ın emriyle Moğol İmparatorluğu'nun batı topraklarına görevlendirilen sivil vâli olup Kafkaslar başta olmak üzere görev alanındaki yerlerde nüfus sayımı yapmış, Moğolların o güne kadar karışık olan vergi sistemini sadeleştirmiştir. Vergi ıslahı konusunda ün yapmıştır. Ayrıntılı bilgi için bkz. Aknerli Grigor, a.g.e., s. 104, 118-119, 124, 127-128, 142, 145, 147; Cüveynî, a.g.e., s. 418-431; Benâketî, a.g.e., s. 452-460; George Lane, "Arghun Aqa: Mongol Bureaucrat", Iran Studies, Vol. 32, Number 4, (Fall 1999), s. 459-482; Ebû'l-Fazl Hatibî, "Argûn Aka", Dânişnâme-i Îrân, C.2, Tahrân 1384 hş., s. 443-444.

${ }^{56}$ Mîrhând, a.g.e., s. 259.

${ }^{57}$ Abû'l-Farac, Abû'l-Farac Tarihi, C. 2, s. 575.

58 Makrizî, a.g.e., s. 133.

${ }^{59}$ Genceli Kiragos, a.g.e., s. 137; Aknerli Grigor, a.g.e., s. 52; Reşîdüddin Fazlullah, a.g.e., s. 62 .

60 Genceli Kiragos, a.g.e., s. 137; Vardan, a.g.e., s. 232; Reşîuüddin Fazlullah, a.g.e., s. 62; Ebû'l-Fidâ, Târîhu Ebî'l-Fidâ, s. 313; Mîrhând, a.g.e., s. 260; Handmîr, a.g.e., s. 99; Spuler, a.g.e., s. 69;Dashdondog, a.g.e., s. 134; El-Ğamdi, a.g.m., s. 237; Alican, a.g.t., s. 180.

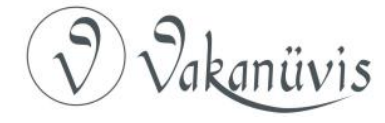


direnen Seyfeddîn Levkili ve Anber-i Habeşînnin atlarının samanı ve arpası kalmadığı için onları öldürüp yediklerini, hatta insanların balık gibi birbirlerini dahi yediklerini kaydetmiştir. ${ }^{61}$ Kaynaklar eti yenecek aciz ve zayıf kimse kalmayınca baba-oğulu, ana-kızı, dost-dostu yemeğe başladı kaydını düşmüşlerdir. Kiragos, bir librelik insan etinin yetmiş sekiz tehegan'a ${ }^{62}$ satıldığını, gitgide bunun bile bulunamaz hale geldiğini kaydetmiştir. ${ }^{63}$ Vardan Vekâyinâmesi'nde bir papazın kıtlık ve insanların birbirlerinin etlerini yemeleriyle ilgili olarak gördüklerini itirafnâme olarak yazdığını, kendisinin de bir canavara dönüşmüşçesine hemcinslerinin etini yediğini ve sonradan günahları için af dilediğini kaydetmiştir. ${ }^{64}$ Kuşatma sürerken şehirde kıtlığın yanında bir de veba salgını baş gösterdi. Hastalık insanların durumunu daha da kötüleştirdi ve can kaybını arttırdı. Bu nedenle şehirde çok az insan kaldı. ${ }^{65}$

Uzun zamandır muhasara altında tutulan Meyyâfârikîn yaz sıcağındaki açlık ve susuzluğa daha fazla dayanamadı. Seyfeddîn Levkili ve Anber-i Habeşî yaya olarak dışarı çıkıp savaşarak ölmek istediler. Fakat el-Kâmil buna izin vermedi. Kalan bu az sayıdaki insan; "Şehirde candan diri, tenden ölü birkaç kişiden başka kimse kalmadı. Eğer bir ordu gelirse karşı koyacak kimse yoktur." diye Yaşmut'a bir mektup gönderdiler. ${ }^{66}$

Bu kıtlık ve veba nedeniyle halkın büyük çoğunluğu öldüğü için elKâmil, Moğolların geri çekilmeleri karşıı̆ı̆ında kaledekilerin teslim olmak istediklerini iletmek için kardeşi el-Eşref Mûsâ'yı gönderdi. Ancak bu

\footnotetext{
${ }^{61}$ Reşîuüddin Fazlullah, a.g.e., s. 62.

${ }^{62}$ Bir tehegan yaklaşık olarak Arapların bir dinârına denktir. Bkz. Genceli Kiragos, a.g.e., s.137. Kiragos; kıtlığın yalnızca Meyyâfârikîn'de değil, civarda da şiddetli şekilde görüldüğünü, bunun sebebinin hem kışın şiddetli geçmesinden hem de Moğolların askerlerini beslemek için halktan zorla ve çok fazla mal almalarından kaynaklandığını kaydetmiştir. Bkz. Kiragos, aynı yer.

${ }^{63}$ Genceli Kiragos, a.g.e., s. 137. Sebasti Vakayinamesi'nde ise bir litr insan etinin yüz dekana (1 litr 326 gram) satıldığı kaydedilmiştir. Sebasti Vakayinamesinden Bir Bölüm, s. 48.

${ }^{64}$ Vardan, a.g.e., s. 232; Vartan Vekayinâmesi, s. 175.

${ }^{65}$ Ebû'l-Fidâ, Târîhu Ebî'l-Fidâ, s. 313; Abû'l-Farac, Târîhu Muhtasari'd-Düvel, s. 41. Bazı kaynaklar veba kelimesi yerine salgın hastalık kaydını düşmüşlerse de belirtilen veba olmalıdır. Cahen, a.g.m., s. 103.

${ }^{66}$ Reşîdüddin Fazlullah, a.g.e., s. 62.
}

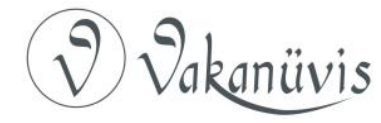


teklifi kabul ediyor gibi görünen Moğollar onu geri göndermediler. ${ }^{67} \mathrm{El}-$ Kâmil'in çaresiz Moğollardan emân dilemesi neticesinde Uruktu Noyan şehre girdi. Moğollar şehre girdiklerinde; Reşîdüddîn Fazlullah yetmiş kişiden başka şehrin tüm ahalisinin öldügünü, Mîrhând ve Hândmîr; şehirde yetmiş sekiz kişi, Abû'l-Farac yüz kişi, İbn Şeddad ise atmış sivil, kırk iki askerin kaldığını kaydetmiştir. ${ }^{68}$

Moğollar iki yıl kuşatma altında tuttukları şehri 1259 yılında teslim aldılar. ${ }^{69}$ Kuşatma sırasında kahramanlıklarıyla ün salan Seyfeddîn Levkili ve Anber-i Habeşî surların üstünde ve evlerin çatısında Moğollara ok atıp onları öldürmeye devam ediyorlardı. Uruktu oraya gelerek adamlarına bunları öldürmelerini emretti. Bu iki savaşçının okları bitince aşağıya inip kalkanlarını siper ederek kılıçlarıyla kahramanlık mücadelesine devam ettiler. Kuşatmanın başından beri yılmaz bir azim ve cesaretle savaşan yiğitler sonunda öldürüldüler. ${ }^{70}$

Zayıf düşen az sayıdaki şehir halkı emân dilemesine rağmen Moğollar onları da katlettiler. Moğol istilâcılar tarafından Meyyâfârikîn'de yapılan

67 Cahen, a.g.m., s. 103. Reşîuüddin ise Mûsâ'nın kuşatma sırasında el-Kâmil ile birlikte ele geçirildiğini kaydetmiştir. Reşîdüddin Fazlullah, a.g.e., s. 62.

68 Abû'l-Farac, Abû'l-Farac Tarihi, C. 2, s. 575; Reşîdüddin Fazlullah, a.g.e., s. 62; Mîrhând, a.g.e., s. 260; Handmîr, a.g.e., s.99; Cahen, a.g.m., s. 103.

${ }^{69}$ Reşîdüddin Fazlullah, Vardan ve Sebasti Vekâyinâmesi, Benâketî, Hândmîr, Mîrhând başta olmak üzere kaynakların büyük çoğunluğu kuşatmanın iki yıl sürdüğünü kaydetmişlerken, Stephanos başta olmak üzere bir kısım kaynaklar bir yıl sürdüğünü kaydetmişlerdir. Aknerli Grigor ise kuşatmanın üç yıl sürdüğünü kaydetmiştir. Reşîdüddin Fazlullah, a.g.e., s.62; Vardan, a.g.e., s. 232; Vartan Vekayinâmesi, s. 175; "Sebasti Vekayinâmesi", Çev. Hasan Oktay, Ermeni Kaynaklarına Göre Türkler ve Moğollar, Selenge Yay., İstanbul 2007, s. 218; Aknerli Grigor, a.g.e., s. 52-53; Abû'lFarac, Târîhu Muhtasari'd-Düvel, s. 40; Benâketî, a.g.e., s. 422; Cahen, a.g.m., s. 103; Piskopos Stepanos'un Vekayinâmesi'nden Parçalar, s. 234; Mîrhând, a.g.e., s. 259; Handmîr, a.g.e., s. 99; Spuler, a.g.e., s. 69; Grousset, a.g.e., s. 343; Jean Paul Roux, Cengiz Han ve Moğol Imparatorluğu, Yapı Kredi Yay., İstanbul 2012, s. 337; Vardan ve Genceli Kirakos ise şehrin 1260 yılında Moğolların eline geçtiğini kaydetmişlerdir. Genceli Kiragos, a.g.e., s.138; Vardan, a.g.e., s. 234. Abû'I-Farac, eğer bu kıtlık olmasaydı Moğolların şehri alamayacaklarını kaydetmiştir. Abû'l-Farac, Târîhu Muhtasari'd-Düvel, s. 40.

70 Reşîuüddin Fazlullah, a.g.e., s. 62; Mîrhând, a.g.e., s. 260; Handmîr, a.g.e., s. 99.

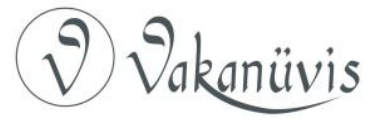


yağma ve tahribat ile şehir harabeye çevrildi. ${ }^{71}$ ibn Şeddad, el-Kâmil'in emân istediği sırada şehirde kalan atmış sivil kırk iki askerin Moğollar tarafından camide toplandığını ve mallarını teslim etmedikleri gerekçesiyle öldürüldüklerini kaydetmiştir. ${ }^{72}$

Meyyâfârikîn çok eski bir Yakubî Piskoposluğu ve Ermenilerin yaşadığı yer olduğu için Hristiyan nüfusu oldukça kalabalıktı. Bunlar muhtemelen kuşatma öncesinde şehri terk etmişlerdi. Böylece hepsi katliamdan kurtulmuştur. Zaten Moğolların Hristiyanlara bakış açısı müspet olduğundan şehir ele geçirildiği sırada orada olsalar bile onlara muhtemelen dokunulmayacaktı. Genceli Kirakos, Moğolların kiliseler ile Aziz Maruta tarafından toplanmış olan mukaddes emanetlere hiç dokunmadıklarını kaydetmiştir. $^{73}$ Moğollar Meyyâfârikîn'i ele geçirdikten sonra buranın idaresini daha önce Eyyûbîlerin Emîr-i Ahûr işlerini yürütmekle görevli olan Abdullah Lâvî'ye teslim ettiler. ${ }^{74}$

\section{c. El-Kâmil'in Akıbeti ve Sonrasında Yaşanan Gelişmeler}

Yanındaki tüm savaşçıları ölen el-Kâmil bir kuleye sığındıysa da yakın adamı Kara Sungur ile birlikte yakalandı. Moğollar, Kara Sungur'u Kence hâkimine teslim ettiler. ${ }^{75}$ El-Kâmil'i ise Yaşmut'un yanına götürdüler. ${ }^{76}$

Yaşmut'a getirilen el-Kâmil oradan Tel-Beşir'e götürülüp ${ }^{77}$ kardeşi Mûsâ ile birlikte Hülagü’nün huzuruna çıkarıldı. Mûsâ hemen öldürüldü. İbn Şeddad'a göre Hülagü, el-Kâmil'in suçlarını yüzüne bir bir saydı. Moğol adetlerinin üç hatayı affedip dördüncüsünde öldürdüklerini; Hemedan'da ona içki ikram ettiği halde içmediğini, Diyarbakır Kalesi'nin

${ }^{71}$ Abû'l-Farac, Târîhu Muhtasari'd-Düvel, s. 40; Genceli Kiragos, a.g.e., s.138; Vassaf, a.g.e., s. 25; Mîrhând, a.g.e., s. 260; Handmîr, a.g.e., s. 99; Savcı, a.g.e., s. 38; Şirin Beyânî, Din û Devlet der Iran Ahd-i Mogul, C. 3, s. 872.

${ }^{72}$ Cahen, a.g.m., s. 103.

${ }^{73}$ Genceli Kiragos, a.g.m., s. 138.

${ }^{74}$ Abû'l-Farac, Abû'l-Farac Tarihi, C. 2, s. 575; Aynı Müellif, Târîhu Muhtasari'd-Düvel, s. 40; Cahen, a.g.m., s. 103; Ayşe Dudu Kuşçu, Eyyûbî Devlet Teşkilatı, TTK, Ankara 2013, s. 180.

${ }^{75}$ Cahen, a.g.m., s. 103.

${ }^{76}$ Genceli Kiragos, a.g.e., s. 138; Reşîuüddin Fazlullah, a.g.e., s. 62; Mîrhând, a.g.e., s. 260; Handmîr, a.g.e., s. 99. Mîrhând ve Hândmîr; Hülagü'nün el-Kâmil'in elinin ve kolunun bağlanarak getirilmesini, adamlarının ise öldürülmesini emrettiğini kaydetmişlerdir. Mîrhând, a.g.e., s. 260; Handmîr, a.g.e., s. 99.

77 Reşîuüddin Fazlullah, a.g.e., s. 63.

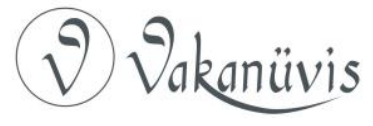


duvarlarını yıkmasını istediği halde bunu yapmadığını ve burayı Türkiye Selçuklu Sultanı'na verdiğini, ordusunu ve mallarını kardeşi ile birlikte halîfeye yardım için sevk etme dediği halde dinlemediğini, dördüncü olarak kendisinin el-Kâmil'in memleketine geldiği halde onun ne huzura geldiğini ne mal ve hediye verdiğini söyledi. El-Kâmil, Hülagü'ye; kendi değerinin onunkinden daha fazla olduğunu, zira kendisini Allah'a ve Peygamber'e havale ettiğini, imân ve itimadının tam olduğunu, kudretin Allah'tan olduğunu, gücü o kime isterse verdiğini, bir zamanlar Tebriz'den Aden'e kadar kendilerinin olduğunu ama kaybettiklerini, Allah'ın Hülagü ve maiyetini kaybetmek ve son neferine kadar öldürmek için adam göndermeye muktedir olduğunu söyledi. ${ }^{78}$

Hülagü; "Kardeşimin sana ikramda bulunup bütün ailene ve akrabalarına Suyurgamışi ${ }^{79}$ vermesinin mükâfatı isyan mıdır?" dedi. ${ }^{80}$ Hülagü kendisine itaat etmemiş olmasından ve Moğol askerlerine karşı direnip kayıplar verdirmesinden dolayı el-Kâmil'e büyük bir kin besliyordu. Bu nedenle vücudundan kesilen etlerin o ölünceye kadar ağzına tıkamalarını emretti. Bu şekilde yapılan işkenceler sonucunda elKâmil öldü. ${ }^{81}$ Abû'l-Farac, Hülagü'nün el-Kâmil'i öldürttükten sonra pişman olduğunu kaydetmiş ancak ayrıntı vermemiştir. ${ }^{82}$ El-Kâmil'in ölüm tarihini Reşîuüddîn 657/1259, Genceli Kirakos, Muharrem-Safer 658/Ocak 1260 olarak kaydetmiştir. ${ }^{83}$

\footnotetext{
${ }^{78}$ Cahen, a.g.m., s. 103.

79 Suyurgamişi: Moğollarda han tarafından bir yerin veya bir görevin ihsan, lütuf veya ikta yoluyla birisine verilmesine denir. Ayrıntılı bilgi için bkz. Özkan Dayı, "Moğollar Döneni Fars Edebiyatında Kullanılan Bazı Türkçe Moğolca Terimler", Atatürk Üniversitesi Türkiyat Araştırmaları Dergisi, S. 63, (2018), s. 487.

80 Reşîuüddin Fazlullah, a.g.e., s. 63.

81 Reşîdüddin Fazlullah, a.g.e., s. 63; Benâketî, a.g.e., s. 422; Mîrhând, a.g.e., s.260; Hândmîr, a.g.e., s. 99; Kirakos el-Kâmil'in nasıl öldürüldüğü konusunda ayrıntı vermemiş ancak Moğollar tarafından öldürüldüğünü kaydetmiştir. Genceli Kiragos, a.g.e., s. 138. Aknerli Grigor, Vardan ve Cûzcânî ise el-Kâmil'in ölümüyle ilgili bir bilgi vermemişlerdir. Aknerli Grigor, a.g.e., s. 52-53; Vardan, a.g.e., 232-233; Cûzcânî, a.g.e., s. 166-171.

82 Abû'l-Farac, Târîhu Muhtasari'd-Düvel, s. 40.

${ }^{83}$ Reşîuüddin Fazlullah, a.g.e., s. 63; Genceli Kiragos, a.g.e., s. 138. Her iki tarih arasında bir yıl gibi bir fark görünüyorsa da aralarında ay farkı vardır. Bu nedenle her iki müellifin verdikleri tarihler birbirlerine çok yakındır ve doğru bir tespittir kanaatindeyiz. Yukarıda da zikredildiği gibi el-Kâmil'in kesik başının dolaştırılarak Şam'a getirilmesi 1260 yılının mayıs ayına rastlamaktadır. Aradaki süre mâkul bir zaman aralığıdır.
}

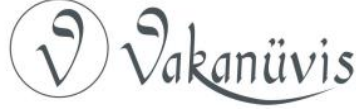


Reşidüddîn; el-Kâmil'in dindar, ekmeğini terzilikten kazanan, Cûzcânî; dindar ve takva sahibi, Ebû'l-Fidâ ise adaletli, sabırlı ve kararlı birisi olduğunu kaydetmiştir. ${ }^{84}$

El-Kâmil'in işkence ile acı bir şekilde öldürülmesinden dolayı Ebû Şâme bir kaside yazdı. Kasidede el-Kâmil'in faziletlerini, cihat eden bir kimse olduğu, mazlum olarak öldürülmesi nedeniyle $\mathrm{Hz}$. Hüseyin'e benzediğini anlattı. ${ }^{85}$

El-Kâmil öldürüldükten sonra ${ }^{86}$ Moğolların zafer nişânesi olarak bir mızră̆ın ucuna takılan kafası, Halep ve Hama başta olmak üzere şehir şehir dolaştırıldı. Daha sonra 27 Cemaziyyelevvel 658/10 Mayıs 1260 tarihinde Şam'a getirilip burada da davul zurna eşliğinde sokaklarda teşhir edildi. ${ }^{87}$

El-Kâmil'in öldürülmesinden büyük bir sevinç duyan ve onun kesik başını teşhir edenler sadece Moğollar değildi. Doğudaki Haçlı Ruhu'nu taşıyan Hristiyanlar da el-Kâmil'in başını bir kafes içinde Şam'daki kaledeki kapıların birinin üzerinde sallandırdılar. ${ }^{88}$ Güyâ onların Müslümanlara karşı bu kadar kin ve nefret duymalarının sebebi; kuşatmada birçok Hristiyan askerin hayatını kaybetmesinin yanında bir Ermeni prensinin de öldürülmesiydi. Bunun yanında Hülagü’nün, hanımı

\footnotetext{
${ }^{84}$ Cûzcânî, a.g.e., s. 166; Reşîdüddin Fazlullah, a.g.e., s .63; Ebû'l-Fidâ, Târîhu Ebî'l-Fidâ, s. 313.

85 ibn Kesîr, a.g.e., s. 381; Ebû'l-Fida, Târîhu Ebî'l-Fidâ, s. 313.

${ }^{86}$ Reşîdüddin Fazlullah, a.g.e., s. 63; Genceli Kiragos, a.g.e., s. 138; Ebû'l-Fidâ, Târîhu Ebî'l-Fidâ, s. 313; ỉbn Kesîr, a.g.e., s. 381-382; Benâketî, a.g.e., s. 422; Mîrhând, a.g.e., s. 260; Handmîr, a.g.e., s. 99.

87 Ebû'l-Fidâ, Târîhu Ebî'l-Fidâ, s. 313; İbn Kesîr, a.g.e., s. 381-382; Abû'l-Farac, Târîhu Muhtasari'd-Düvel, s. 40 dn.2; Cahen, a.g.m., s. 103; Grousset, a.g.e., s. 343; Roux, a.g.e., s 337; El-Ğamdi, a.g.m., s. 240; Curtin, a.g.e., s. 274; Cengiz Tomar, "Bir Devrin Sonu Eyyubiler", Eyyubiler Yönetim, Diplomasi, Kültür ve Hayat, Ed. Önder Kaya, Küre Yay., İstanbul 2012, s. 154.

88 El-Ğamdi, a.g.m., s. 240.
}

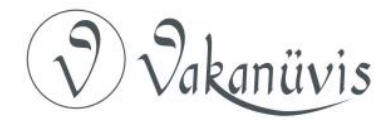


Dokuz Hatun'un ${ }^{89}$ etkisiyle Hristiyanlara karşı duyduğu sempati de Hristiyanlar tarafından Müslümanların aleyhine istismar edildi. ${ }^{90}$

El-Kâmil'in başı Aynicâlût Savaşı'ndan sonra Şam'ın Memlûklerin eline geçmesine kadar el-Ferâdis kapısında asılı kaldı. ${ }^{91}$ El-Kâmil'in ve Meyyâfârikîn halkının Moğollara karşı vermiş olduğu bu direniş örneği dünya hâkimiyeti peşinde koşan Moğolların durdurulmasının belki de ilk adımı olmuş, Memlûkler 25 Ramazan 658/3 Eylül 1260 tarihinde kazandıkları Aynicâlût Savaşı ile Moğolları yenerek onların yenilemeyeceği düşüncesine son verdiler. Memlûkler şehri ele geçirdikten sonra el-Kâmil'in asılı duran başını indirip el-Re's Camii'nde Hazreti Süleyman Şehitliği olarak bilinen yerde defnettiler. ${ }^{92}$

Bir kavşak noktasında bulunan Meyyâfârikîn, kuşatma sırasında ve alınmasından sonraki tahribatta çok büyük yaralar almıştır. Ancak bu tahribata rağmen 1336 tarihli illhanlı devlet bütçesi ile ilgili rakamları veren Hamdullah Müstevfi-yi Kazvinî́nin, Meyyâfârikîn'in Hani ile birlikte gelirinin 224 bin dinâr olduğunu kaydetmesi dikkate alındığında şehrin kısa zamanda toparlandığı anlaşılmaktadır. Bu rakamı bölgedeki diğer bazı şehirlerle karşılaştırdığımızda Meyyâfârikîn'in gelirinin bölgede en fazla olan şehirlerden biri olduğu görülür. Örneğin Mardin 236 bin, Sincâr 147 bin 500, Muş 69 bin 500 dinârdır. Moğollar tarafından tahrip edilen Meyyâfârikîn'in geliri ile ilgili yüksek rakam şehrin kısa zamanda yine Moğollar zamanında toparlandığını göstermesi bakımından önemlidir. ${ }^{93}$

89 Dokuz Hatun, Hülagü’nün baş hatunudur. Nesturudî Hristiyandır. O, Hristiyanları korur onların haklarını savunurdu. Hülagü'den dört ay sonra 1265 yılında ölmüştür. Bkz. Reşîdüddin Fazlullah, s. 4; Aknerli Grigor, a.g.e., s. 57, 65; Abbas İkbal, a.g.e., s. 171; Şirin Beyânî, Moğulân ve Hükûmet-i ilhânî der Irân, s. 102, 182; Vartan Vekayinâmesi, s. 175. 90 Grousset, a.g.e., s. 343; Yuvalı, a.g.e., s. 128-129. Nitekim Aknerli Grigor, Hülagü'nün Hristiyanları, kiliseyi ve papazları çok sevdiğini kaydetmiştir. Aknerli Grigor, a.g.e., s. 56. 91 Ebû'I Fidâ, Târîhu Ebî'l-Fidâ, s. 313.

92 Ebû'l Fidâ ve ibn Kesîr, el-Kâmil'in kesik başının el-Ferâdis Kapısı'nın civarındaki Mescidü'r-Res'deki Hz. Hüseyin'in kesik başının yanına defnedildiğini kaydetmişlerdir. İbn Kesîr, a.g.e., s. 381-382; Ebû'l Fidâ, Târîhu Ebî'l-Fidâ, s. 313.

93 Hamdullah Müstevfî-yi Kazvînî, Nuzhat al-Qulub, s. 105; Zeki Velidi Togan, "Moğollar Devrinde Anadolu'nun İktisadi Vaziyeti", Türk Hukuk ve Iktisat Tarihi Mecmuası, S. 1, (Istanbul 1931), s. 26-27.

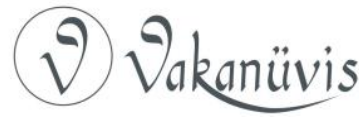




\section{Sonuç}

Hülagü Han 1256 yılında Bâtınîlere, 1258 yılında Abbâsî Halîfeliği'ne son verdi. Bölgede kendisine rakip olacak bir güç bırakmak istemediği için çeşitli bahaneler ileri sürerek oğlu Yaşmut'u, illigya Noyan ile birlikte Eyyûbîlerin Kuzey Mezopotamya'daki kolunun önemli şehirlerinden biri olan Meyyâfârikîn üzerine gönderdi. Şehrin halkıyla bütünleşen el-Kâmil burada Moğollara karşı adeta bir kahramanlık destanı yazdı. Şehir kuşatıldığı için kıtlık ve bulaşıcı hastalık onların direncini kırdı. ỉki yıl süren kahramanlık mücadelesi el-Kâmil ve yanındaki az sayıdaki insanın teslim olmasıyla son buldu. Hülagü'nün huzuruna götürülen el-Kâmil yapılan ağır işkencelerle öldürüldü. Ancak onun zulme karşı direnişi bir simge olarak yüzyıllar boyunca destansı şekilde dilden dile dolaştı. Hakkında birçok keramet anlatıldı. Meyyâfârikîn ise eski önemini yitirerek bir süre sıradan bir kasaba olarak kaldı.

Meyyâfârikîn kuşatmasında şehir halkının yöneticisiyle bütünleşerek gösterdiği direniş hareketi, Moğollara karşı nadir olarak başvurulabilen cesur olaylardan birisidir. Çünkü daha Moğollar gelmeden, onların yaptıkları yağma ve katliam hareketlerini duyan şehirler çoğu zaman sindirilmiş ve yenilgiyi kabul etmiş bir şekilde kendiliklerinden teslim oluyorlardı.

Kuşatmanın kahramanı el-Kâmil, doğuda Hârezmşah Sultanı Celâleddîn'in Parvan Savaşı'nda ve Sind Nehri'nin kıyısında Moğollara karşı gösterdiği kahramanlık öyküsünü hatırlatmaktadır. Hatta Celâleddîn'den buyana uzun süredir Moğollara karşı bu kadar şiddetli bir direniş hareketi de görülmedi denilse yanlış olmaz.

\section{Kaynakça}

Abbas İkbal Aştiyânî, Târîh-i Moğol ez Hamle-yi Cengiz tâ Teşkîl-i Devlet-i Timûrî, Müesse-yi İntişârât-i Emîr-i Kebîr, Tahran 1986.

Ahmed b. Ali Makrizî (ö. 845/1442), Kitâbü's-Sülûk fî Marifeti Düvel elMülûk, C. 1, Bölüm 2, Yay. M. Zaide, Kâhire 1936-38, Türkçe Tercüme Zakir Kadiri Ugan, TTK Tercüme Eserler Bölümü Yayınlanmamış Daktilolu Tercüme Yazmalar Kısmı.

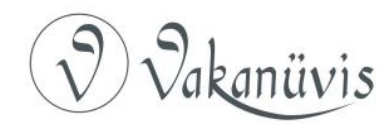


Akkuş, Mustafa, "Hülâgû Han Döneminde Anadolu'da Görev Yapan Moğol Komutanları", Necmettin Erbakan Üniversitesi Sosyal Bilimler Enstitüsü Dergisi, S. 9, (Konya 2018), s. 150-171.

Aknerli Grigor (ö. 1335), Okçu Milletin Tarihi, Yeditepe Yay., İstanbul 2012.

Alaaddîn Ata Melik Cüveynî (ö. 681/1283), Tarih-i Cihan Güşa, Çev. Mürsel Öztürk, TTK, Ankara 2013.

Alican, Mustafa, Bir Orta Çağ Şehri Olarak Meyyâfârikîn (Silvan), Ege Üniversitesi Sosyal Bilimler Enstitüsü Tarih Anabilim Dalı Yayınlanmamış Doktora Tezi, İzmir 2012.

Barthold, V.V., Moğol istilâsına Kadar Türkistan, Çev. Hakkı Dursun Yıldız, TTK, Ankara 1990.

Benâketî, Fahreddîn Ebû Süleymân Dâvûd b. Tâcu'd-dîn (ö. 730/13291330), Târîh-i Benâketî (Ravzât ûî'l-Elbâb fî Ma'rifeti't-Tevârîh ve'l-Ensâb), Ed. Ca'fer Şi'ar, Tahran 1348.

Boyle, J. A., "Dynastic and Political History of The II-Khāns", Cambridge History of iran, Vol. 5, (Cambridge 1968), s. 303-421.

Cahen, Claude, "XIII. Asır Ortalarında Cezire (İzzeddin b. Şeddada Göre)", Çev. Neşet Çağatay, Ankara Üniversitesi Ilahiyat Fakültesi Dergisi, C. 2, S. 4, (Ankara 1952), s. 93-106.

Celâleddîn Suyûtî (ö. 911/1505), Halifeler Tarihi, Arapçadan Çev. Onur Özatağ, Kabalcı Yay., İstanbul 2001.

Curtin, Jeremiah, The Mongols A History, Barton 1908.

Dashdondog, Bayarsaikhan, The Mongols and the Armenians (1220-1335), Vol. 24, Ed. Michael R. Drompp Devin DeWeese, Leiden-Boston 2011.

Dayı, Özkan, "Moğollar Döneni Fars Edebiyatında Kullanılan Bazı Türkçe Moğolca Terimler", Atatürk Üniversitesi Türkiyat Araştırmaları Dergisi, S. 63, (2018), s. 485-498.

D'ohsson, Abraham Constantin Mouradgea, Moğol Tarihi, Haz. Ekrem Kalan, IQ Kültür Sanat Yay., İstanbul 2014.

Ebû'l-Fazl Hatibî, "Argûn Aka”, Dânişnâme-i Îrân, C.2, Tahrân 1384 hş., s. 443-444.

Ebû'l-Fidâ, (ö.732/1331), Târîhu Ebî'l-Fidâ el-Müsemmâ el-Muhtasar fî Ahbâri'l-Beşer, C. 2, Tahkîk Mahmûd Deyyûb, Beyrut 1997.

Ebû'l-Fidâ, (ö. 732/1331), Ebü'l-Fidâ Coğrafyası, Çev. Ramazan Şeşen, İstanbul 2017.

El-Belâzurî, (ö. 279/892), Fütûhu'l-Büldân, Çev. Mustafa Fayda, Kültür Bakanlığı Yay., Ankara 1987.

"Ermeni Müellifi Kiragos", Çev. Hasan Oktay, Ermeni Kaynaklarına Göre Türkler ve Moğollar, Selenge Yay., İstanbul 2007, s. 15-100.

Genceli Kiragos (ö. 1265'ten sonra), Moğol İstilası 1220-1265, Çev. Mahmut Kemal Bey, Post Yay., İstanbul 2018.

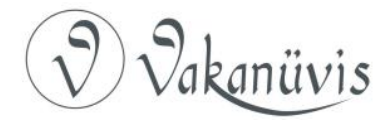


Gregory Abû'I-Farac Bar Hebraeus (Ebü'l-Ferec İbnü'l-ibrî ö. 1286), Abû'lFarac Tarihi, C. 2, Çev. Ömer Rıza Doğrul, TTK, Ankara 1999.

Gregory Abû'l-Farac Bar Hebraeus (Ebü'l-Ferec İbnü'l-ibrî), Târîhu Muhtasari'd-Düvel, Terc. Şerafeddin Yaltkaya, TTK, Ankara 2011.

Grousset, Rene, Bozkır Imparatorluğu Atilla-Cengiz Han-Timur, Çev. M. Reşat Uzmen, Ötüken Yay., İstanbul 1999.

Hamdullah Müstevfî-yi Kazvînî (Hamd-Allah Mustawfi of Qazwîn ö. 740/1340), The Geographical Part of the Nuzhat al-Qulub, Trans. G. Le Strange, Leyden/London 1919.

Hamdullah Müstevfî-yi Kazvinî, Târih-i Güzide, Çev. Mürsel Öztürk, TTK, Ankara 2018.

Hândmîr (ö. 942/1535-1536), Târîh-i Habîbu's-Siyer fí Ahbârî Efrâdi'l-Beşer, C. 3, Neşr. M. N. Debir Siyâkî, Kitâbfurûşî-yi Hayyam, Tahran 1362.

Hillenbrand, Carole, “Mayyafarikin”, El², Vol. 6, Leiden 1991, s. 928-932.

Hudûdü'l-Âlem Mine'l-Meşrik Ile'l-Magrib, Çev. Abdullah Duman-Murat Ağarı, Kitabevi Yay., İstanbul 2008.

İbn Havkal (ö. 977), 10. Asırda is/âm Coğrafyası, Terc. Ramazan Şeşen, Yeditepe Yay., İstanbul 2014.

İbn Kesîr (ö. 774/1373), El Bidâye Ve'n-Nihâye (Büyük İslam Tarihi), C. 13, Çev. Mehmet Keskin, Çağrı Yay., İstanbul 1994.

İbni Tagrıberdi (ö. 874/1470), En-Nücûmu'z-Zâhire (Parlayan Yıldızlar), Arapçadan Çev. Ahsen Batur, Selenge Yay., İstanbul 2013.

İbn'ül-Ezrak (587/1181?), Mervanî Kürtleri Tarihi, Çev. Mehmet Emin Bozarslan, Koral Yay., İstanbul 1975.

Kadı Ahmed b. Muhammed-i Gaffarî-yi Kazvinî (ö. 975/1567), Târîh-i Cihanârâ, Kitâbfurûşi-yi Hâfız, Tahran 1963.

Kafalı, Mustafa, "Cengiz Han", DiA, C.7, s. 367.

Minhâc-i Sirâc el-Cûzcânî (ö. 664/1266'dan sonra), Tabakât-ı Nâsırî (Moğol İstilasına Dair Kayıtlar), Çev. Mustafa Uyar, Ötüken, Ankara 2016.

Minorsky, V., "Meyyâfârikîn”, i. A., C. 8, MEB, İstanbul 1979, s. 195-201.

Mîrhând (ö. 903/1498), Ravzâtu's-Safâ fí Sîreti'l-Enbiyâ ve'l-Mülûk ve'lHulefâ, C. 5, Kitâbfurûşîha-yi Merkezi Hayyam, Neşr. Çapepirûz, Tahran 1339.

Müverrih Vardan (ö. 1271), Türk Fütühatı Tarihi (889-1269), Türkçe Çev. Hrant D. Andreasyan, Milli Mecmua Basımevi, İstanbul 1937.

"Piskopos Stepanos'un Vekayinâmesi'nden Parçalar", Çev. Hasan Oktay, Ermeni Kaynaklarına Göre Türkler ve Moğollar, Selenge Yay., İstanbul 2007, s. 231-245.

Reşîdüddin Fazlullah (ö. 718/1318), Câmiu't Tevârih (IIhanlılar Kısmı), Çev İsmail Aka vd. TTK, Ankara 2013.

Roux, Jean Paul, Cengiz Han ve Moğol Imparatorluğu, Yapı Kredi Yay., İstanbul 2012.

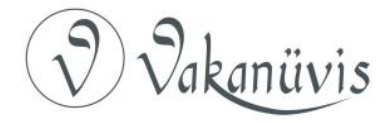


Sa'd b. Muhammed Huzeyfe el-Ğamdi, “Meyyafarikin'de Kahramanlık ve Fedakârlık", Çev. Mehdi i̇han, AÜDTCF Tarih Araştırmaları Dergisi, C. 29, S. 47, (Ankara 1986), s. 227-242.

Savcı, Süleyman, Silvan Tarihi (Mafarkın Âbide ve Kitabeleri), Diyarbakır Matbaası, Diyarbakır 1956.

Savran, Ahmet, "Meyyâfarikîn", DiA, C. 29, s. 511-512.

"Sebasti Vakayinâmesinden Bir Bölüm", Çev. A. G. Galstyan, Ermeni Kaynaklarına Göre Moğollar, Rusçadan Çev. Ilyas Kamalov, Yeditepe Yay., İstanbul 2005, s. 39-61.

"Sebasti Vekayinâmesi", Çev. Hasan Oktay, Ermeni Kaynaklarına Göre Türkler ve Moğollar, Selenge Yay., İstanbul 2007, s. 210-229.

Spuler, Berthold, Iran Moğolları, Çev. Cemal Köprülü, TTK, Ankara 2011.

Strange, Guy Le, Doğu Hilafetinin Memleketleri, Çev. Adnan Eskikurt-Cengiz Tomar, Yeditepe Yay., İstanbul 2015.

Subaşı, Ömer, Gürcü Moğol Ilişkisi Güney Kafkasya 1220-1346, Kitabevi Yay., İstanbul 2015.

Şirin Beyânî, Din û Devlet der Iran Ahd-i Mogul: Siyâset-i Hâricî ilhânân der Cihan-ı İslâmî, C. 1-3, Merkezi Neşr-i Dânişgâhî Tahran 1370.

Şirin Beyânî, Moğulân ve Hükûmet-i ilhânî der Irân, Tahran 1394.

Temir, Ahmet, “Moğol veya Türk Moğol Hanlığı”, Türkler Ansiklopedisi, C. 8, Yeni Türkiye Yay., İstanbul 2002, s. 416-433.

Togan, Zeki Velidi, "Moğollar Devrinde Anadolu'nun İktisadi Vaziyeti”, Türk Hukuk ve Iktisat Tarihi Mecmuası, S. 1, (İstanbul 1931), s. 26-27.

Tomar, Cengiz, "Bir Devrin Sonu Eyyubiler", Eyyubiler Yönetim, Diplomasi, Kültür ve Hayat, Ed. Önder Kaya, Küre Yay., İstanbul 2012, s. 143-155.

Uyar, Mustafa, IIhanlı (İran Moğolları) Devleti'nin Askerî Teşkilatı, TTK, Ankara 2020.

"Vartan Vekayinâmesi", Çev. Hasan Oktay, Ermeni Kaynaklarına Göre Türkler ve Moğollar, Selenge Yay., İstanbul 2007, s.165-188.

Vassaf (ö. 730/1329-1330), Tahrir-i Târîh-i Vassaf, Neşr. Abdu'I-Muhammed Âyetî, Bünyâd-i Ferheng-i İran, Tahran 1346.

Venegoni, Laura, "The Political Backround of the Mongolian Conquest and Hülagü's West Conquest (1256-1260)", Hacettepe Üniversitesi Türkiyat Araştırmaları Enstitüsü Dergisi, S. 6, (Ankara 2007), s. 29-40.

Yahyâ b. Abdüllatif Kazvinî (ö. 962/1555), Lübbû't-tevârîh, Intişârât-i Bünyâd-i Gûyâ, Tahran 1363.

Yuvalı, Abdulkadir, Ilhanlı Tarihi, Bilge Kültür Sanat Yay., İstanbul 2017. 